\title{
HIBRID TROLIKKAL A KULTURÁLIS ÉS SZAKMAI PROGRAMOKRA
}

\section{Gál József - Tóth István Tibor - Véha Antal - Keszthelyi-Szabó Gábor}

\begin{abstract}
Absztrakt: A kultúra és a szakmai programok iránt érdeklődő lakosság és a turisták megelégedettségére a Szegedi Közlekedési Kft. időszakos trolibuszjáratokkal biztosította a rendezvényekre eljutást és a hazautazást. A hibrid trolibuszok csendes közlekedése elnyerte a lakosság elismerését - föleg - éjszakánként. A jövőben újabb vonalak felmérésére kerül sor, ahol járhatnak a korszerü Ikarus-Skoda önjáró trolibuszok.
\end{abstract}

\begin{abstract}
Inhabitants and tourists interested in cultural and vocational programs are satisfied about Szeged Public Transport Ltd. because this company ensured temporary trolleybuses travelling to events and home. Silent hybrid trolleybuses are accepted and liked - mainly during night - by inhabitants. Further lines will be examined where modern Ikarus-Skoda self-powered trolleybuses can be operated in the future.
\end{abstract}

Kulcsszavak: hibrid trolibusz, nyári programok, Szeged, Ikarus-Skoda, környezetvédelem Keywords: hybrid trolleybus, summer events, Szeged, Ikarus-Skoda, environmental protection

\section{Bevezetés}

Szeged mindennapjaiban jelentős szerepet kapnak a különböző kulturális és szakmai programok. Nyaranta rendszeresek a színházi előadások, tematikus múzeumi kiállítások. A Város életének komfortosabbá tétele érdekében a Szegedi Közlekedési Kft. (SZKT) színházi járatokat üzemeltet az előadások alkalmával, igazodva azok tényleges befejezési idejéhez. A Dóm tér rendezvényeihez legközelebbi utasfelvételi lehetőség az Aradi vértanúk terén van, ahol az 1 és 2-es villamosok már sok éve várják a színház utáni utasaikat. A vonalhálózat kötöttségéből adódóan mozgásterük korlátozott (Bodrogi, 2009), így kiváló ötletnek tủnt az önjáró, azaz felsővezetékről és akkumulátorról is üzemeltethető trolibuszok bevonása ebbe a speciális utasforgalomba. Ebben a formában a trolibuszokkal lefedhetővé válik Szeged több olyan kerülete is, ahová éjszaka közösségi közlekedéssel nem lehet eljutni. Az utasok körében végzett kérdőíves felmérés alátámasztja, hogy megkedvelték e környezetbarát lehetőséget, de még ennél is fontosabb számunkra, hogy a 21. század technikai színvonalának megfelelő kényelmi berendezésekkel felszerelt, korszerủ utastájékoztató rendszerrel ellátott trolibuszokról van szó (alternativenergia.hu, 2013). A lakosság azt is kiemelte, hogy a zajterhelés nemcsak a jármüvek belsejében kisebb, hanem az utcazaj erőssége is megváltozott, így az elsuhanó trolibuszok kevésbé zavarják a pihenni vágyókat ezeken az éjszakákon.

\section{Bor tér és Repülőnapok}

Az ország legkiválóbb bortermelői gyültek össze immár hatodik alkalommal a szegedi Dóm téren megrendezésre kerülő Bor téren. Eddig minden évben igyekeztek a szervezők becsempészni programjaik közé borkultúránk egy-egy 
szeletét, idén sincs ez másként. A Bor térre idén is kiváló szakemberek hozták el boraikat, sokan látogattak el az eseményre és kóstolták meg a rendezvény borválasztékát és gasztronómiai különlegességeit (Varga, 2016a).

A legkiválóbb borokhoz természetesen a legkiválóbb muzsikaszó dukált, éppen ezért a Bor tér az idei évben is színvonalas zenei programokkal várta a minőségi nedűk szerelmeseit. Szeptember 14-es és 18-a között minden eddiginél több, összesen 111 pincészet kínálta nem nedüit a Dóm téren, továbbá több mint 30 kézműves portékái közül válogathattak, és a vendéglátósok finomságait is megízlelhették (webradio.hu, 2016).

A program jellegéből adódóan a vendégek alkoholtartalmú italokat is fogyasztottak, így nem vezethettek jármủveket hazafelé menet. A rendezvényhez kapcsolódó időszakos járatok menetrendjére és útvonalára az 1. ábrán szereplő információs pontok hívták fel a figyelmet, melyet a tömegkommunikáció több csatornáján is népszerüsítettek.

\section{1. ábra: A Bor tér megközelítését segítő önjáró trolibuszok menetrendjének tájékoztatója}

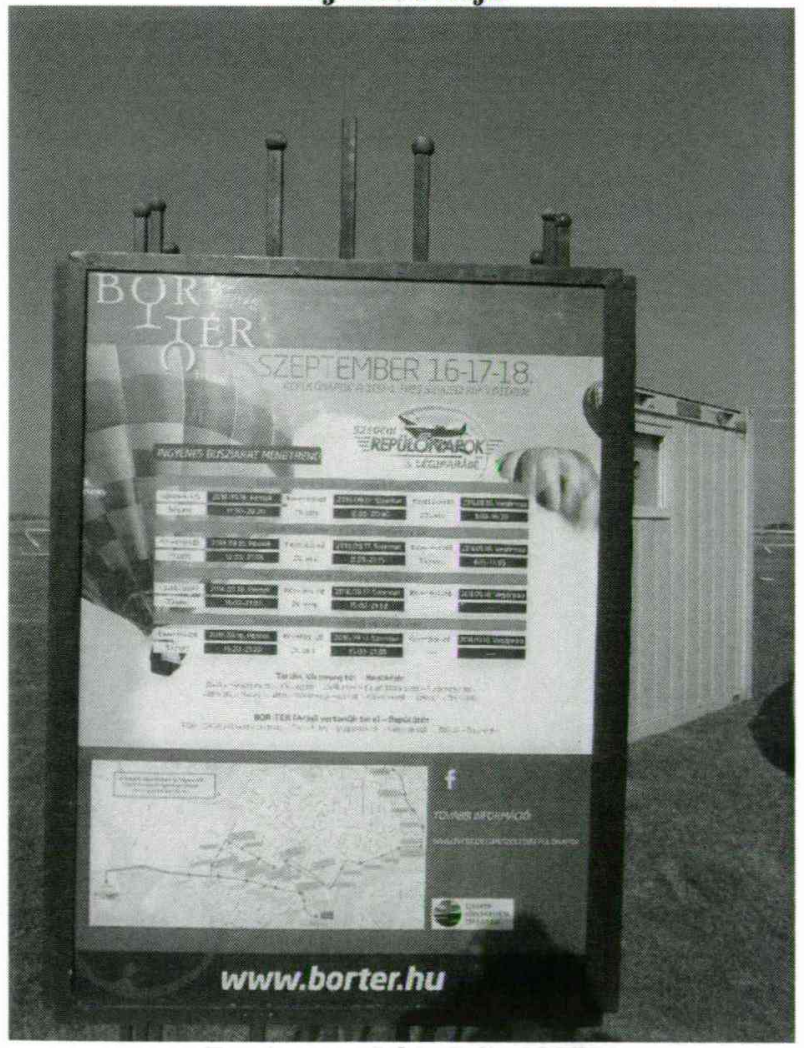

Forrás: szerző felvétele (2016)

Szeged légtere is ünnepelt, a repülőtér ugyanis $100+1$ éves. A több mint 30 tematikus program között vadászrepülőgép bemutató, kötelékrepülés, kupola 
formaugrás is várta az érdeklődőket, de volt bungie jumping helikopterből, érkezett Besenyei Péter mürepülő világbajnok, továbbá Ábrányi Tamás mürepülő is ámulatba ejtette a repülőtér közönségét. Az L-29 Delfin sugárhajtású kiképző repülögép már pénteken is tartott bemutatót, míg szombaton a világ egyetlen repülőképes Li-2-ese is Szeged fölé emelkedett, akárcsak egy Dragonfly ultrakönnyü gép, de mezőgazdasági repülőket is felvonultattak. Mivel a szegedi repülőtér születésnapjáról van szó, természetesen a helyi repülőgépek is felvonultak.

Pénteken napnyugta körül érkeztek meg a hőlégballonok, igaz akadt olyan versenyző, aki elsodródott, s nem tudott a repülőtéren leszállni. Sokan voltak kíváncsiak az olasz Pioneer Team gyakorlóprogramjára, akiknek a bemutatóját szombaton délután is meg lehetett tekinteni. A péntekre meghirdetett záró programot, a zenére komponált hőlégballonos látványshowt is kivárták a látogatók, igaz sokan arra számítottak, hogy a levegőbe is emelkednek majd a fényben úszó ballonok (Varga, 2016b).

A rendezvényre szintén menetrendszerü trolibuszjáratokat biztosított az SZKT, melyekre a jól ismert bordó hibrid trolibuszokkal közlekedtek (2. ábra).

\section{2. ábra: Repülőnapokra közlekedő hibrid trolibusz}

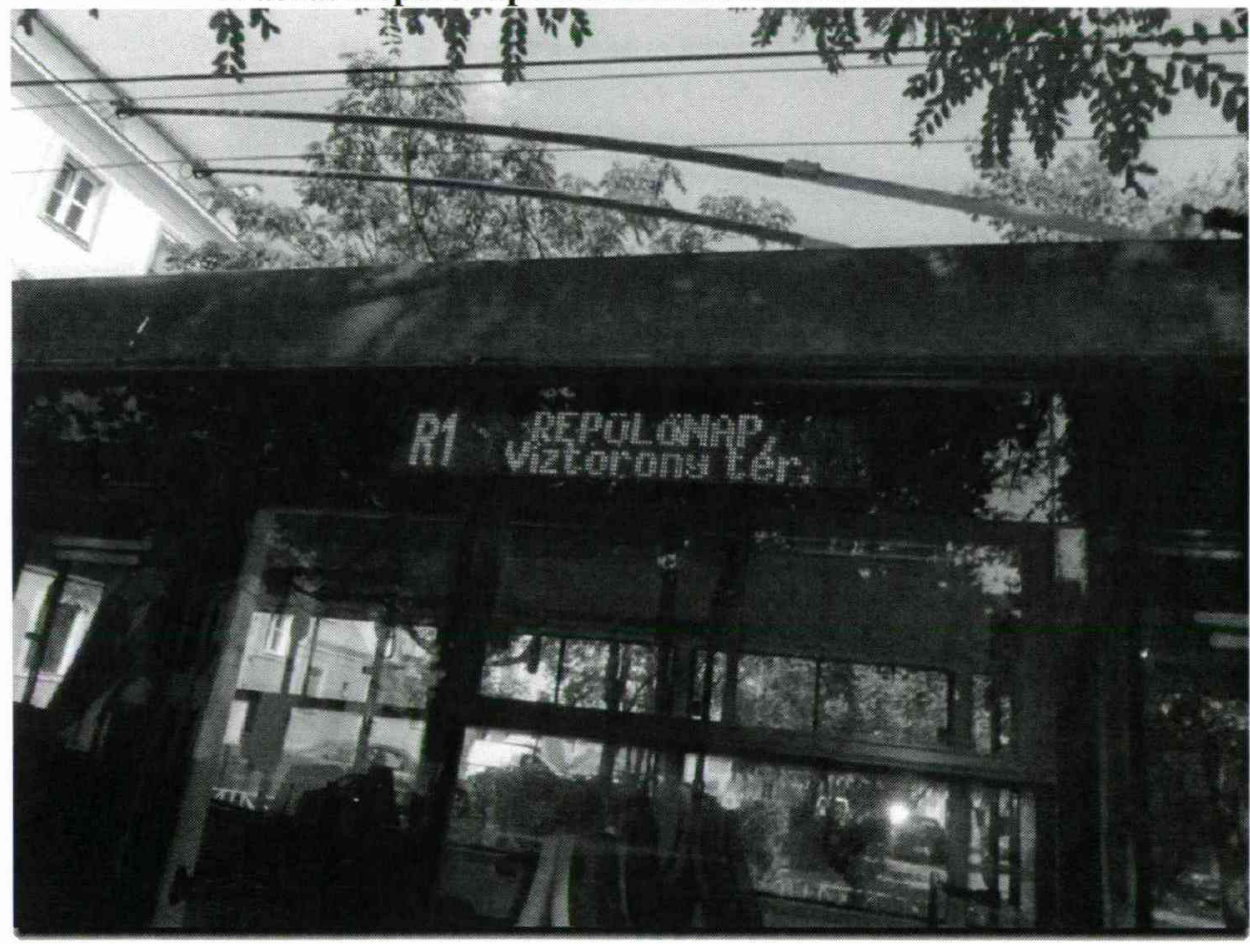

Forrás: szerző felvétele (2016) 
Az érdeklődők először furcsán szemlélték a lehúzott áramszedőkkel közlekedő járműveket, illetve többek részéről kérdésként merült fel a hálózathoz kapcsolódás műszaki megoldása, amely a 3. ábrán látható.

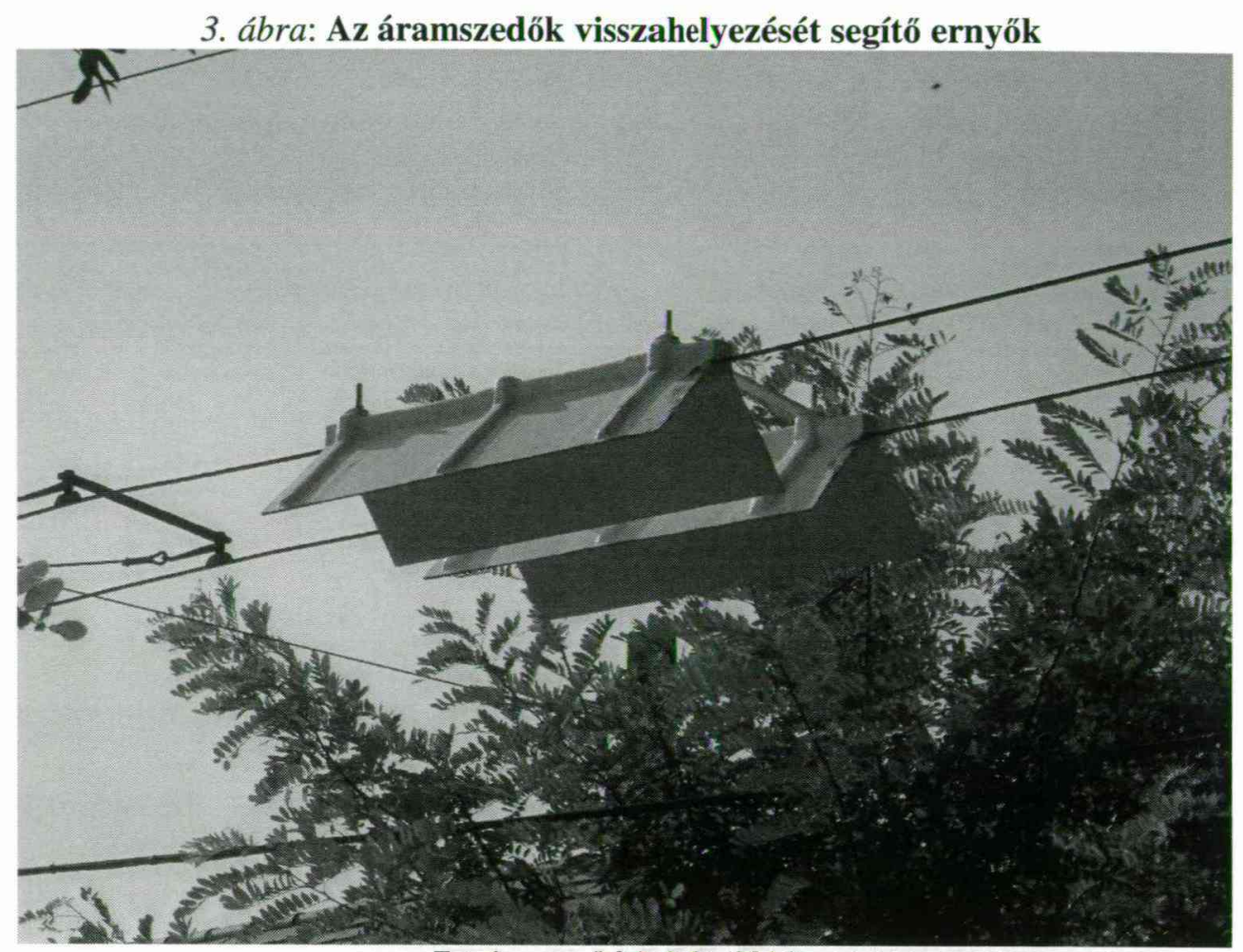

Forrás: szerző felvétele (2016)

\section{3. Összegzés}

Ezen gondolaton felbátorodva született meg a döntés, hogy más rendezvények esetében is érdemes a Bor Tér 2016. szeptember 16-18. programjaihoz igazodó vonal meghatározása, illetve annak kiterjesztése a Szegedi Repülőnapok, Légiparádé repülőtéri helyszínéig. Az egyik járat a Víztorony térről indulva haladt keresztül több kerületen, majd a belvároson, a másik járat az Aradi vértanúk teréről vette az irányt a Szegedi Repülötér felé érintve a hétvége fontosabb rendezvényeinek helyszíneit. A járatsürüség ütemezett menetrenddel valósult meg. A jármüvek - itt is az önjáró csuklós trolibuszokról van szó - csak a kiemelt, nagy érdeklődésre számot tartó események esetében voltak magas kihasználtságúak, annak ellenére, hogy a városlakók többször, különböző információs forrásokból is tudomást szerezhettek ezekről a céljáratokról. Itt is érezhető volt - annak ellenére, hogy az utasok díffizetés nélkül vehették igénybe a szolgáltatást - a megszokottságnak nagy szerepe van utazási szokásaik megvalósítása során. Sokan indultak személygépkocsival, fizettek parkolódíjat és sétáltak többet, mintha a járattal mentek volna - talán - ebben egyfajta átgondolatlanság is érezhető volt. Az 
ELIPTIC projekt egyik kiemelt célja annak feltérképezése, hogy a hibrid üzemmódban működtethető trolibuszok milyen extra szolgáltatások végzésére lehetnek alkalmasak Szeged területén, illetve hogyan szolgálhatják a fenntartható közösségi közlekedést alakítva, fejlesztve a lakosság gondolkodását e területen.

\section{Irodalomjegyzék}

Bodrogi B. P. (2009): Magyarországi trolibusztörténet. Volos Kiadó, Mogyoród.

webradio.hu (2016): Bortér Szeged 2016. Öszi bormustra a Dóm téren, <http://webradio.hu/szegedi_programok/rendezveny/D3MCTV4P6A>. (2016.09.08.)

alternativenergia.hu (2013): Önjáró trolibuszt mutattak be Szegeden, <http://www.alternativenergia.hu/tag/szeged/page/3>. (2016.10.13.)

Varga A. (2016): Bortér és repülőnapok - Szeptember közepi égi és földi ünnep Szegeden. $<$ http://szegedma.hu/hir/szeged/2016/09/borter-es-repulonapok-szeptember-kozepi-egi-esfoldi-unnep-szegeden.html>. (2016.09.08.)

Varga A. (2016): Légi-, majd sötétedés után fényparádéval nyitott a szegedi repülönapok. <http://szegedma.hu/hir/szeged/2016/09/legi-majd-sotetedes-utan-fenyparadeval-nyitott-aszegedi-repulonapok-fotok.html>. (2016.09.17.)
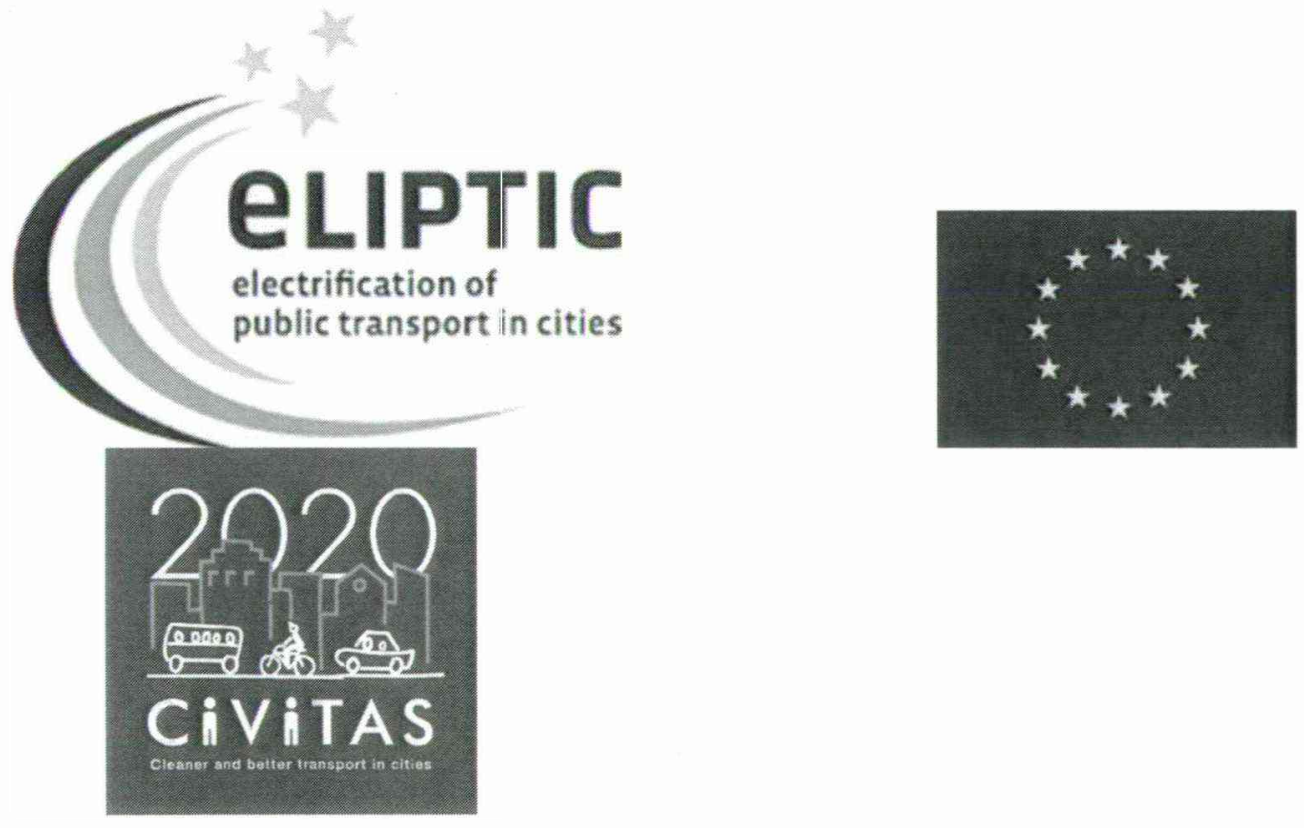

This project has received funding from the European Union's Horizon 2020 research and innovation programme under grant agreement No 636012. 